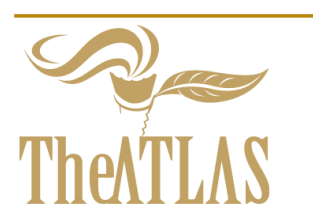

\title{
Poetry and Quantum Physics: Towards the Same Realism?
}

\author{
Bénédicte Letellier, Faculty of Arts and Social Sciences, University of Reunion Island, Saint-Denis, France, E-mail: \\ benedicte.letellier@univ-reunion.fr
}

Received 10 January, 2019; Revised 28 February, 2019; Accepted 14 March, 2019

Copyright (C)2019 Bénédicte Letellier. This is an open access article distributed under the Creative Commons Attribution License (https://creativecommons.org/licenses/by/4.0/), which permits unrestricted use, distribution, and reproduction in any medium, provided the original work is properly cited.

Available online 15 March, 2019 at www.atlas-journal.org, doi: 10.22545/2019/0121

\section{-} his chapter focuses on the concept of reality in Adonis' poetry and the theoretical physics developed by Basarab Nicolescu. Do they conceive reality in the same way? In this brief comparison, I seek to show that, despite different languages, poetry and quantum physics tend towards the same realism, namely the deep conviction of a veiled Real manifesting itself under numerous faces. These two activities that aim to know and reflect reality are based on how we live our relationships with all forms and at all scales of life. Consequently, they depend on both the object as an absolute entity and the subject who lives it, that is, on the subject-object connection. Beyond this famous relativism which is not the only criterion for the quantum and poetic conception of reality, the main debate, which will be mine in this article, concerns the absolute existence of the objective reality and therefore the way to access and describe it.

Keywords: Reality, real, realism, poetry, physics, Adonis, Basarab Nicolescu.

\section{Introduction}

In the 15th canto of his long poem titled Adoniada, Adonis wrote this enigmatic sentence: "Life is a metaphor although it has been called reality" ${ }^{1 "}$ Given this unusual definition of life, Adonis changes the main postulate of the classical conception of reality, namely the image is not reality, it is rather a copy. He also subverts the common idea - reality is true whereas a copy is false - by conceiving image and reality as identical forms. According to the conception of a new materiality of life - based on images, how could we be wary of images, as for example the French poet Philippe Jaccottet invited us to do in $1975 ?^{2}$ In fact, even his poems are carried by a reverie. Then, how could he truly avoid the deep immersion in images? In 1987, as he himself acknowledged in A Secret Transaction, he finally betrayed the model of "a poetry without images" that he had imposed on himself and explained this change saying: "I got carried away over the images.

\footnotetext{
${ }^{1}$ Adonis, Adoniada is a collection of unpublished poems I am translating into French. "Wal-hayat majâz wa in sumiyyat wâqi'an" (my translation).

${ }^{2}$ Philippe Jaccottet, $\grave{A}$ travers un verger, Paris, Gallimard, édition électronique, 2015 (1984), empl. 83. "Méfie-toi des images".
} 
[...] I let reborn in me the metaphor of the night.." ${ }^{3}$ In fact, he could not access to reality without the images because, as Adonis puts it, "everything is a metaphor". ${ }^{4}$ In the same way, Basarab Nicolescu wrote in The Hidden Third that "in our age it's no longer the image that has to conform to reality, but reality that has to conform to the image." ${ }^{5}$ To put it quickly, Adonis and Basarab Nicolescu conceive the figurative expression both as an informed shape that we have to refer to and as a starting point for rethinking reality. It means that the figurative expressions are not a copy of the reality but it is rather its manifestation, that is to say a form that manifests and veils the Real in the same time. From this point of view, they are not only a tool for describing and revealing the Real - therefore creating or consolidating a reality - but also a tool for measuring and experiencing it.

\section{Mathematical and Poetic Languages}

On hearing that the Manhattan project supremo Robert Oppenheimer was writing poems, a puzzled Dirac remarked in a rare outburst of transdisciplinary criticism: "I do not see how a man can work at the frontiers of physics and write poetry at the same time. They are in opposition. In science, you want to say something nobody knew before, in words which everyone can understand. In poetry, you are bound to say something that everybody knows already in words that nobody can understand." This anecdote, well-known amongst theoretical physicists, expresses the idea that poetry is fundamentally useless since its language is incomprehensible and what it seeks everyone already knows. It is an ancient and famous story since Plato: poetry is regularly condemned and banned for different reasons. But, Dirac's objection is unfair. It may be supposed here that Dirac did not know what is really at stake in poetry, not to mention

\footnotetext{
${ }^{3}$ Philippe Jaccottet, Une transaction secrète. Lectures de poésie, Paris, Gallimard, édition électronique, 2015 (1987) empl. 384. "je me suis laissé emporter au fil des images; jai laissé renaître au fil des images ; j'ai laissé renaître en moi la métaphore de la nuit". (My translation).

${ }^{4}$ Adonis, Adoniada, unpublished, song XX. "Kullu shay' majâz." (My translation).

${ }^{5}$ Basarab Nicolescu, The Hidden Third, translated into English by William Garvin, Quantum Prose, 2016 (1994), p.67.
}

his bad faith about mathematical language. Indeed, like most of poems, Dirac's fundamental equations are not immediately accessible to everyone. In fact, his biographer Graham Farmelo has compared his equations to haikus. Despite Dirac's objection to poetry, the following question arises: would he not have finally tried to compete with poetry? His aesthetic sensibilities were similar to those of the poets. He was fascinated by the beauty of mathematical formulas claiming that beauty lies in mathematics. When he argues, as quoted above, that science increases knowledge and approaches the truth through a clear language, he implies that the beauty of this language is a sign of truth. In other words, the mathematical beauty would be understandable, not to say universal, because of its simplicity and elegance, and therefore mathematical beauty would above all guarantee access to knowledge and truth. However, beside these two aesthetic criteria of beauty common to those of poetry, no offense to Dirac, is there no other fundamental but invisible criterion? In the article of The Guardian on the 21st November 2016 about Dirac's equations, "Magic Numbers: Can Maths Equations Be Beautiful?" 6 , Ian Sample adds a criterion and explains beauty as follows:

What does it mean for maths to be beautiful? It is not about the appearance of the symbols on the page. That, at best, is secondary. Maths becomes beautiful through the power and elegance of its arguments and formulae; through the bridges it builds between previously unconnected worlds.

Indeed, mathematics translate into equations these bridges that are possible "between previously unconnected worlds". Curiously, Ian Sample uses a metaphor here to describe a common scientific experiment, namely the observation or creation of possible links between unconnected worlds. Yet, in 1994, Basarab Nicolescu had already given a scientific name - inspired by philosophy of science and logic, to the image of "bridge" as evoked in the poetic theorem below:

A bridge between the unknown and the unthinkable: The Hidden Third. Thus, the

\footnotetext{
${ }^{6}$ Ian Sample, "Magic Numbers: Can Maths Equations Be Beautiful?", The Guardian, Nov. 2016. Consulted on the 6th December 2018, https://www.theguardian.com/science/2016/nov/21/magicnumbers-can-maths-equations-be-beautiful
} 
known and the thinkable are born. (2016: 22)

Similarly, it can be argued that poetry translates the Hidden Third into poems. To quote Adonis, for example, whose poetry is an attempt to show the possible and invisible links between us and the unknown, his last long poem can be read as an epic to the unknown or an invitation to explore the unknown. He uses the same metaphor to describe the interconnection between human and cosmos as in these lines:

Do not imitate

that creator -

Invent

a new creator for a new futur

and say with ardor:

between heaven and me, there are only

bridges

of air and dust. ${ }^{7}$

But, unlike Ian Sample, Adonis suggests here that we are all connected to the cosmos as if we were to first accept this postulate to honestly observe and acknowledge our present situation in the world, and then begin to truly explore our invisible connections with different worlds. The "bridges of air and dust" literally refer to these connected phenomena and their related scientific questions such as: what is the matter? Or what is the light? Or what is the reality? In this poetic model of the world, the main idea is that, as Basarab Nicolescu puts it about Gregorio Morales involved in the quantum aesthetics' movement, "everything is interconnected, non-separated" 8 . Despite the fact that Adonis did not seek to create a quantum aesthetic in his poems, the reader can easily acknowledge a view of life similar to that of Morales. In this type of aesthetics, the reader can see the collapse of dichotomies such as "matter" versus "mind" or "spirit" because the metaphor itself (re-)actualizes the potential information available in the Real. To recall the general definition, the metaphor represents something, invisible or not. But it does not just create a shape or an image. It also reveals a connection with something else. The metaphor is the mental movement that associates one thing with another. In other words,

\footnotetext{
${ }^{7}$ Adonis, Adoniada, unpublished, song XI. (My translation)

${ }^{8}$ Basarab Nicolescu, From Modernity to Cosmodernity: Science, Culture, and Spirituality, New-York: SUNY Press, 2014, empl. 3124.
}

it is a kind of a geometrical translation that is necessarily also a transformation and that can be noted both by equations and poems.

\section{Connected Worlds and the Hidden Third}

Thus given a metaphor, we must accept the mental displacement from a reality to another to understand it and see the reality differently. This means that a metaphor or an equation is initially hermetic and requires one to experiment with a new point of view. In this respect, "life is really a metaphor although it has been called reality". In Arabic, Adonis used the word "majâz" which I translated above as "metaphor". However, in Arabic rhetoric, as explained by Nejmeddine Khalfallah in his doctoral dissertation, Jurjânî, a renowned Persian scholar of the Arabic language dead in 1078, called "majâz" "any reasoned change of meaning or language, departing from the usual way of expressing oneself" . Thus, to be more precise, I should have rather translated "majâz" by "figurative expression" because the "majâz" encompasses all the tropes that signify the transition from a proper meaning to a figurative sense. According to the dictionnaries, this Arabic notion includes the comparison (tashbih), the metaphor (isti'âra) and the analogy (tamthîl), namely rhetorical processes based on similarity or differentiation. Thus, the very original conception of figurative expression of Jurjânî is very useful here to compare equations with poems, or the scientific language with the poetic one because both use figurative expressions structured by logical links. As demonstrated by Jurjânî and explained by Nejmeddine Khalfallah, the meaning and the value of figurative expressions derive from the logical relation that connects the two terms of an equivalence or an image, hence the figure of speech conceived by Jurjânî as "a logical equation". ${ }^{10}$ This kind of logical equation does not figure the principle of the dialectic based on an antagonism. We must rather understand it as the expression of the "trialectic" that Stéphane Lupasco coined to describe antagonistic dynamics. Nourished by the

\footnotetext{
${ }^{9}$ Nejmeddine Khalfallah, La théorie du Ma'nâ d'après 'Abd al-Qâhir al-Jurjâni (d. 1078), Paris: L'Harmattan, 2011, p. 179 .

${ }^{10}$ Nejmeddine Khalfallah, La théorie du Ma'nâ d'après 'Abd al-Qâhir al-Jurjâni (d. 1078), Paris: L'Harmattan, 2011, p. 179 .
} 
thought of Heisenberg and Bohr, Stéphane Lupasco wrote many books about the logic of the included third and the binary thought. He showed that contradictory energies cannot exist outside a ternary structure noticeable by their dynamics. It means that dynamics or "the logic of the energy", as named by Lupasco, implies a state $\mathrm{T}$ that includes the two contradictory terms, hence the expression of the included third. In other words, as Basarab Nicolescu puts it, "in a triad of the included third, the three terms coexist at the same moment in time". ${ }^{11}$ In sum, the trialectic or "the logic of the energy" must be figured by three terms: A, non -A and T. But to what extent is a logical equation or a figurative expression inherent to the logic of the energy? In other words, to what extent is a figurative expression the sign of the included third? Basarab Nicolescu answers in a very innovative way in his latest essay, From Modernity to Cosmodernity: Science, Culture and Spirituality (2014). Indeed, he shows that the logic of the energy allows us to compare the quantum world and the psychic world, or to be more precise, to compare their representations of the reality. $\mathrm{He}$ relies on Lupasco's philosophical reflection to highlight the logic of energy at work in the symbol. His commentary on the included third must be repeated here:

The included third does not mean at all that one could affirm one thing and its opposite - that, by mutual annihilation, would destroy any possibility of prediction and therefore any possibility of a scientific approach of the world. It is rather about recognizing that in a world of irreducible interconnections (such as quantum world), conducting an experiment and interpreting experimental results are inevitably reduced to a cutting up of the real, which affects the real itself. [...] Due to the rigorous development of his axiomatic formalism, Lupasco postulated the existence of a third type of antagonistic dynamics, which coexists with that of heterogeneity, which governs living matter, and with that of homogeneity, which governs macroscopic physical matter. This new dynamic mechanism assumes the

\footnotetext{
${ }^{11}$ Basarab Nicolescu, From Modernity to Cosmodernity: Science, Culture, and Spirituality, Albany, State University of New York Press, 2014, ebook, empl. 2582.
}

existence of a state of rigorous, precise balance between the poles of a contradiction, in a strictly equal quasi-actualization and quasi-potentialization. This state, which Lupasco calls the $\mathrm{T}$ state ("T" being the initial for the included "third"), characterizes the quantum world and the psyche world. ${ }^{12}$

But this state T remains totally logical. As defined by Lupasco, it cannot unify contradictories because the contradictories themselves are located in the area of resistance, namely the main characteristic of reality. Scientists define reality in terms of resistance. Therefore, Basarab Nicolescu distinguishes the words Real and Reality as follows:

Real designates that which is; Reality is connected to resistance in our human experience. "The Real" is, by definition, veiled forever (it does not tolerate any further qualifications); but "Reality" is accessible to our knowledge. ${ }^{13}$

However, a fundamental characteristic of the included third was missing here to explain more exactly how it could unify contradictories. Basarab Nicolescu complete the formulation of a unified theory with the Heisenberg's model of different levels of Reality and the concept suggested by Michel Camus of "the secretly included third". According to him, "the zone between two different levels and beyond all levels is a zone of nonresistance to our experiences, representations, descriptions, images, and mathematical formulations". ${ }^{14}$ This is precisely the secretly third, named by Basarab Nicolescu "the Hidden Third", that crosses the area of nonresistance and ensures the unity. One can understand here that the binary logic is deadly whereas the ternary logic based on the Hidden Third is fundamental. To quote a poetic theorem of Basarab Nicolescu: "Binary logic is deadly. Always seek the Hidden Third." ${ }^{15}$ The Hidden Third and the symbol are based on a ternary structure. But do they have a similar role in the logic of the energy? As written by Gilbert Durand and quoted by Basarab Nicolescu, "the symbol is [...] a representation which makes a secret meaning appear,

\footnotetext{
${ }^{12}$ Ibid., empl. 2662.

${ }^{13}$ Ibid., empl. 4161.

${ }^{14}$ Ibid., empl. 4237.

${ }^{15}$ Basarab Nicolescu, The Hidden Third, Ibid., p. 112.
} 
it is the epiphany of a mystery." 16 Comparing the scientific thinking and symbolic thinking, Basarab Nicolescu states that "the symbol and the logic of the included third are intimately linked" ${ }^{17}$ mainly because the symbol implies the unity of the contradictories. Therefore, we can say that the difference between the symbol and the figurative expression is similar to the difference between the hidden third and the included third. Thus, one can easily understand here to what extent arts can provide to each of us fundamental experiences, especially poetry.

The genius of the poet consists in showing the profound and sometimes unsuspected unity at work in the poem insofar as it governs the principle of symbols and even figurative expressions. By reading this kind of poetry, we can really feel it and be literally touched by its expressions so deeply that, at the same time, we are immediately linked to the Real despite our difficulty to grasp its deep meaning. Admitted that reality is what resists at all level of perception, the Hidden Third is the link that expresses and reveals unity between all levels and the Real is what encompasses all realities, including the poem itself. Therefore, the Real is unity and the poem is its most accessible truth. In Adoniada, Adonis uses very often the word "path" / tarîq which is quite different from the word "bridge" / jisr. The first has many meanings that includes the following notions: the road, the method, the manner, the means, the creed and the direction. "I will sing the path", says the poet. Although Basarab Nicolescu used the bridge to represent the Hidden Third, the poetic path is in fact, in this poem, a symbol par excellence that functions as the hidden third while the bridge is rather the proper image of the included third.

\section{Poetry and Quantum Physics: A Symbolic Path to the Real?}

Poetry or quantum physics, remain a symbolic path to the Real. In this sense, the path is the main feature of a new realism common to these two disciplines as well as to others. The path is the index of a quest itself, scientific or spiritual, and of all its experiments rather than an access to the knowledge of the world or humanity. The richness of this word,

\footnotetext{
${ }^{16}$ Basarab Nicolescu, From Modernity to Cosmodernity: Science, Culture, and Spirituality, Ibid., empl. 732.

${ }^{17}$ Ibid., empl. 742.
}

besides its several meanings, lies in the fact that it has both individual and universal scope. The individual path gives meaning and direction to our life and, therefore, shapes our way of life whereas the universal path is the discovery of spaciousness. As a symbol, the path unites the subject and the object, and harmonizes the vision, the language and the act of displacement in a rare rightness. To take an example, in Adoniada, the path first refers to the road taken by the poet from Syria to France, which is the terrestrial road of his exile. And we know that exile exists only through the idea of the separation of East and West on Earth. How else could we feel in exile if the Earth was seen and lived in its unity? This is somehow the implicit bet that Adonis makes when he says in these lines:

Is the East distanced from the West, giving its heavens to another moon? I will continue my journey.

Everything is metaphor.

Thus, his journey or path is not only terrestrial, passing from one country to another, but it is also spiritual. The external exile is the image of an inner exile far from the Real. It should be noted here that Adoniada is presented as a poetic testament that recounts the poet's most important journeys, hence the title derived from his name Adonis. It is clear that even his memory of exile brings East and West together in one path that is Adonis' body. Here is an example of the way the poet suggests the unity of East and West through the evocation of Sindbad and Ulysses:

Is the East behind me and the West not in front of me?

Two banks for a single river Sindbad
ventures into the Ulysses' sea on a planet
that does not consist of East and West,
one single body

But this long poem, also written as a realistic epic, bears witness to a wandering path that has lost the poet in the unknown or spaciousness.

Where does my path lead? As if the discovery of the path

was a misguidance 
What is at stake here is precisely the discovery of a spaciousness in the body. To put it in another way, the path literally disorientates the one who seeks a destination. It leads to the spaciousness whether in the body or in the cosmos. And the path can be inscribed in the core of poetry as is the case in Adonis poem, or in theories of quantum physics, as is the case in the poetic theorem of Basarab Nicolescu. To quote one of his eloquent theorems:

The shortest path from the infinitely small to the infinitely large is through the infinitely conscious. ${ }^{18}$

To repeat, spaciousness could be felt in the cells of the body and result in a feeling of disorientation that causes especially confusion of thoughts. Therefore, in poetry, the common language no longer becomes understandable because it reveals spaciousness in the moment rather than it expresses a kind of temporality. And the poet longs for this disorientation because the thought is always an illusion while disorientation, namely the path to the unknown, is a path to the Real. The confusion that appears to the reader of a poem is precisely the first step towards the Real insofar as the symbolic language connects different levels of reality and highlights that zone of non-resistance where the hidden third or the symbol acts. The reader no longer needs to understand the meaning. It is enough for him or her to feel the movement from one level of reality to another. In Adonis' poem, the body, the Earth and the cosmos are different levels of reality connected by symbols. The path is one of them. As suggested by the poetic theorem of Basarab Nicolescu cited above, it leads to spaciousness that is consciousness. Or, to say it with the words of Adonis, "the universe is penetrated and deflowered by a consciousness that is neither you, nor her, nor him, nor us, nor them". So, we can feel here the presence of the consciousness because the poet wrote a poetic testament that is neither a commitment in a story nor a legacy of thoughts and beliefs, but rather the testimony of a possible obliteration of the subject and the object.

\section{What If the Path to the Real was Deeply}

\footnotetext{
${ }^{18}$ Basarab Nicolescu, The Hidden Third, Ibid., p. 140.
}

\section{Unscientific?}

When Baudelaire said that "every gifted poet has always been realistic", ${ }^{19}$ he requires the poet to be a meticulous observer of the outer and inner world. In an article titled "Realism in Poetry", Sophie Guermès summarizes the links between French poetry and realism at the turn of the twentieth century saying: "Thus, from Baudelaire to Cocteau, realism in poetry, for those few who venture to bring the two terms together, is a lyricism based on observation and sensation, and - logical consequence but not necessary - tending to the globalization". ${ }^{20} \mathrm{In}$ France, we can notice that the main debate about realism in poetry remains focused on the following question: which of the subject or object is the closest to the Real or the most reliable? Neither or both, answered a few poets. As noticed by Sophie Guermès, French poets of the twentieth century sought to describe the very act of poetry. She takes the example of Yves Bonnefoy to explain how, during the emergence of a so-called "objective literature" (Roland Barthes), he defended the idea of a "subjective intelligible" ("un intelligible subjectif") that can reveal "the truth of speech". Unlike other poets who conceive the reality from a classical thinking based on separation, Yves Bonnefoy makes the poetry "the resource of the path". ${ }^{21}$ According to him, the word itself is intelligence because it can break our engagement with the object of memory and leave us in the pure presence of the Being.

Thus, poetry leads us to a larger consciousness where our personal relationship with the outer world is no longer meaningful. To define realism in poetry, Bonnefoy gives a more accurate and interesting expression. Poetry is, as he puts it, an "initiatory realism" if it opens up to the Real by arousing in ourselves the feeling of the presence. It is in the pure presence that, according to Bonnefoy, the world exceeds the "objective intelligible" ("intelligible objectif") of a scientific approach. In this respect, many poets such as Bonnefoy think that science cannot lead us to what is, as directly as a poem. For ex-

\footnotetext{
${ }^{19}$ Charles Baudelaire, "Puisque réalisme il y a", in Euvres complètes, Paris : Gallimard, La Pléiade, 1954, p. 992.

${ }^{20}$ Sophie Guermès, "Du réalisme en poésie", ["Realism in Poetry"], Poétique, vol. 166, no. 2, 2011, pp. 171-184 [my translation].

${ }^{21}$ Yves Bonnefoy, "L'acte et le lieu de la poésie", ["The Act and the Place of Poetry"], in L'improbable et autres essais, Paris : Gallimard, 1992, p. 131.
} 
ample, Saint-John Perse whose poetry has strongly influenced Adonis states in his speech at the Nobel banquet that "the real in the poem seems to inform itself". ${ }^{22}$ However, unlike Bonnefoy who was wary of images, Perse explains the complicity between the Real and the poem as follows:

By the analogical and symbolic thinking, by the distant illumination of the mediating image, and by the set of its correspondences, on a thousand chains of reactions and foreign associations, by the grace finally of a language where the movement itself of Being is transmitted, the poet invests himself in a surreality that cannot be that of science. ${ }^{23}$

Adonis is more severe: "In vain, I question the science: there is science only mixed with ignorance". Even if Perse says something true about poetry, can we really say, like some poets, that the path to the Real is unscientific?

To answer briefly, we can argue that the presence, never defined by Bonnefoy, is a self-consistency. Suppose that this presence is perceptible at all levels of reality, but, in fact, we can only apprehend it at a certain level which depends on the optimum conditions of observation. In physics, the self-consistency is known as the bootstrap principle. According to Basarab Nicolescu, the bootstrap model, coined by Geoffrey chew in the 60s, "has emerged as a natural reaction against classical realism". ${ }^{24}$ In this model, the terms reality and real are no more conceived as a set of entities characterizing material substance and, therefore, as entities objectively measurable. But, as explained by Basarab Nicolescu, "the bootstrap principle is both organizational and structuring: an infinite number of self-consistency conditions determine the existing particles in a unique way". ${ }^{25}$ It has important consequences developed by Basarab Nicolescu in his essay as follows:

The bootstrap has important implications for the nature of scientific prediction. The knowledge of the whole claims a long and

\footnotetext{
${ }^{22}$ Saint-John Perse, "Discours de Stockholm", in Euvres complètes, Paris : Gallimard, La Pléiade, p. 444.

${ }^{24}$ Basarab Nicolescu, From Modernity to Cosmodernity: Science, Culture, and Spirituality, Ibid., empl. 1870.

${ }^{25}$ Ibid., empl. 1906.
}

patient investigation. Therefore, it must be admitted that one looks for ways of approaching self-consistency with the conviction that behind the approximation hides a fundamental coherence, a rational order without gaps: once we obtain partial information of the real world, knowledge of the rest of the world is not arbitrary - it is obtained by self-consistency. ${ }^{26}$

Although a partial bootstrap such as the hadron bootstrap is scientifically productive and effective, Basarab Nicolescu acknowledges, like Chew himself, that "under its very general form, the bootstrap principle has, with the current state of knowledge, an unscientific character". ${ }^{27}$ As described above, the bootstrap has the symbol properties. Thus, it would be, as Basarab Nicolescu puts it in his poetic theorems, "a bootstrap of words" 28 that, nevertheless, remains an "open theory".

\section{Conclusion}

To conclude this short comparative study, we must remember that poetry and quantum physics offer models of the reality and the Real based on a principle of unity and self-consistency. This is the common vision of these two disciplines. Beyond the lexicons specific to each of them, we can consider this vision of the world as the same realism.

Funding: This research received no external funding.

Conflicts of Interest: The author declare no conflict of interest.

\section{About the Author}

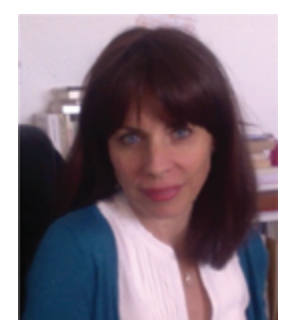

Bénédicte Letellier is associate professor in Comparative Literature at the University of Reunion Island since 2008. Her research is mainly devoted to the comparative

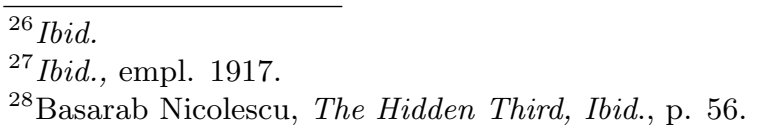


study of Arabic, European and Indian Ocean literatures. She has been series Editor-in-chief since 2017 for the NonWestern Literatures of Connaissances et Savoirs, that is supervised by an international scientific committee. She is the author of Penser le fantastique en context arabe (Thinking the Fantastic in an Arab Context) (2010) and a French translation of an essay written by the Arab poet Adonis, Al-Sufiyya wa al-suryaliya (Soufism and Surrealism) (2016). 